\title{
Association between a frequent variant of the FTO gene and anthropometric phenotypes in Brazilian children
}

\author{
Carmela Farias da Silva', Marília Remuzzi Zandoná2, Márcia Regina Vitolo², Paula Dal Bó Campagnolo², \\ Liane Nanci Rotta², Silvana Almeida ${ }^{2}$ and Vanessa Suñé Mattevi ${ }^{1,2,3^{*}}$
}

\begin{abstract}
Background: Our goal was to analyze the association of the fat mass and obesity- associated (FTO) gene rs9939609 variant (T/A) with the anthropometric and dietary intake phenotypes related to obesity in Brazilian children.

Methods: We analyzed the association of this single nucleotide polymorphism (SNP) with phenotypes related to the accumulation of body mass in a cohort of 348 children followed from the time of birth until 8 years old and then replicated the main findings in an independent schoolchildren sample $(n=615)$.

Results: At the age of 4 , we observed a significant association between the A/A genotype and a higher mean BMI $Z$-score $(P=0.036)$. At the age of 8 , the $A / A$ individuals still presented with a higher $B M l Z$-score $(P=0.011)$ and with marginal differences in the volume of subcutaneous fat $(P=0.048)$. We replicated these findings in the schoolchildren sample, which showed that those with at least one copy of the A allele presented with a higher BMI $Z$-score $(P=0.029)$ and volume of subcutaneous fat $(P=0.016)$.

Conclusion: Our results indicate that this FTO variant is associated with increased body mass and subcutaneous fat in Brazilian children beginning at the age of 4.
\end{abstract}

Keywords: Childhood obesity, FTO gene and genetic susceptibility

\section{Background}

Childhood obesity is an increasing public health problem all over the world, including many low- and middle-income countries. This complex disease is a major cause of morbidity and mortality; a higher risk of obesity is associated with premature death and disability in adulthood. According to the World Health Organization (WHO), 1.6 billion adults (aged 15 years and older) were overweight and 400 million were obese in 2005. By 2015, these figures are predicted to rise to 2.3 billion overweight adults and over 700 million obese adults [1].

Characteristics of the Western lifestyle such as excessive energy intake and low levels of physical activity largely influence the increasing prevalence of obesity worldwide.

\footnotetext{
* Correspondence: vmattevi@ufcspa.edu.br

${ }^{1}$ Programa de Pós-Graduação em Patologia, Universidade Federal de Ciências da Saúde de Porto Alegre, Porto Alegre, RS, Brazil

${ }^{2}$ Programa de Pós-Graduação em Ciências da Saúde, Universidade Federal de Ciências da Saúde de Porto Alegre, Porto Alegre, RS, Brazil

Full list of author information is available at the end of the article
}

In addition to environmental factors, genetic factors also clearly contribute to obesity-related phenotypes, with heritability estimates ranging from over $50 \%$ to $60 \%$ for body mass index (BMI) [2].

A recent Genome Wide Association study (GWAs) for type 2 diabetes mellitus (T2DM) susceptibility genes identified common variants in the FTO gene (fat mass and obesity associated) that predispose adults to diabetes through an effect on BMI [3]. Several single nucleotide polymorphisms (SNPs) have been described in this gene, but a T-to-A change in intron 1 (rs9939609) is the most widely investigated and is consistently associated with obesity-related phenotypes, mainly body mass index (BMI). Approximately $63 \%$ of all individuals of European origin carry at least one A - risk allele of this FTO variant, $16 \%$ being A/A homozygotes [4]. The risk of being obese correlated to each A allele ranges from 1.35 to 1.76 [5].

Of the many tissues in which the FTO gene is highly expressed, the hypothalamic nuclei are of particular 
interest because the nuclei control energy balance and are influenced by nutritional signals [6,7]. However, the exact role of the FTO gene product in the regulation of human energy metabolism is still unclear. While there is some evidence indicating that the FTO gene product functions during early infancy [3], many questions persist regarding the timing of gene function and what systems are affected.

Multiple studies have associated FTO polymorphisms with obesity in different European populations, thereby making this gene one of the most important loci implicated in polygenic obesity thus far [8]. However, the contribution of the FTO common variants to obesity is controversial in African American, Asian (Chinese Han and native Oceanic) and Hispanic populations [9-13]. To our knowledge, there are no studies in Brazil addressing the effect of $F T O$ variation on BMI in children.

In the present study, we analyzed the association between the FTO rs9939609 gene variant and predisposition to weight gain by profiling excessive accumulation of body mass and diet composition in a cohort of children followed from the time of birth until the age of 8 years old. The major findings were then replicated in another independent sample of children.

\section{Methods}

\section{Cohort sample}

In a previous study conducted by our group, 500 motherchild pairs were recruited at birth between October 2001 and July 2002 at Centenario Hospital, the only publicly funded hospital of São Leopoldo, RS, Brazil, and randomized into intervention and control groups. The intervention group followed a program of dietary guidelines: "Ten steps to healthy eating for children under two years" [14]. The intervention consisted of dietary advice about breastfeeding and adequately introducing complementary foods. The intervention group was monitored with home visitations within 10 days of the child's birth, then on a monthly basis up to 6 months and subsequently at 8, 10 and 12 months. Trained fieldworkers provided dietary counseling to the mothers based on the Ten Steps. No subsequent intervention was performed. The prerequisites for the study were a birth weight heavier than 2500 grams and a gestational age of more than 37 weeks. Mother-child pairs were excluded if they possessed any of the following characteristics: HIV positive mother, congenital malformation, infant referred to the Intensive Care Unit and multiple deliveries. The parents reported their ethnicity according to their skin color as white or non-white, which follows the standards of the official population censuses in the country.

The children who completed the first phase of the study $(n=397)$ were reevaluated at the age of 3 to 4 years old at home by trained interviewers to collect food and anthropometric data [15]. Blood samples for biochemical and genetic analyses were also collected at this time. Informed consent was obtained from the parents, and the protocol was approved by the Ethics Committee of the Federal University of Health Sciences of Porto Alegre, $n^{\circ} 736 / 08$.

After reaching the age of 7 to 8 years, the same children were again assessed for dietary, metabolic and anthropometric data $(\mathrm{n}=308)$, and blood samples were collected for biochemical measurements.

\section{Dietary patterns}

At 12 to 16 months of age, undergraduate nutrition students recorded the child's food intake for a 24-hour period prior to the home visit. When the children turned 3 to 4 years old, the dietary patterns were recorded from the food intake diaries for two randomly selected and nonconsecutive 24-hour periods, the first performed at home and the second during the ambulatory evaluation. To quantify the food portion size, pictures were used to illustrate units of measurement, such as teaspoons, tablespoons, cups and food portion.

At 7 to 8 years old, the children were revisited in their homes to assess their diet. Two food intake diaries were recorded over a 24-hour period: the first was documented at home and the second was performed along with anthropometric measurements at school.

The nutritional values for the diets were calculated using the NutWin (Nutritional Support Program from the Federal University of São Paulo), food chemical composition tables [16,17], and information obtained from food industries for products not included in the tables. The mean food intake from the two dietary diaries at 3 to 4 years and at 8 years old was used for analysis.

\section{Anthropometry}

The anthropometric data were collected during three phases. During the first phase, between 12 and 16 months of age, the weights of the children were measured using a portable digital scale (Techline ${ }^{\circ}$ São Paulo, Brazil), and their heights were measured using a portable stadiometer (Seca ${ }^{\circ}$ Hamburg, Germany) with the children dressed in light clothing and no shoes. At 3 to 4 years old, the height, weight, tricipital and subscapular skinfold thickness and waist circumference were measured during the second phase of data collection. The sum of the two individual skinfolds was computed. The body mass index (BMI) was calculated, [weight $(\mathrm{kg}) /$ height $\left.(\mathrm{m})^{2}\right]$, and the values were transformed into a Z-score according to the WHO Growth Standards specific for sex and age. When the children reached 8 years, new anthropometric evaluations were performed. The methodology used was the same as that described above.

\section{Replication sample}

To replicate the previous findings, a total sample of 615 school children and adolescents (4 to 18 years old) was 
used in this work. This sample is part of a cross-sectional study performed in Sapucaia do Sul, RS, Brazil, which was approved by the Ethics Committee of the Federal University of Health Sciences of Porto Alegre, $n^{\circ} 792 / 11$.

After the parents provided written informed consent, blood samples $(5 \mathrm{~mL})$ were collected, and data regarding age, gender and phenotypic characteristics were obtained through a questionnaire that was recorded on the same day on which the blood samples were collected. The anthropometric data were collected as previously described.

\section{Molecular analyses}

DNA was extracted from whole blood using the previously described method of precipitation with a high salt concentration [18].

The FTO variant rs9939609 was genotyped through real-time polymerase chain reaction with the use of an allele discrimination assay (TaqMan SNP genotyping assay) from Applied Biosystems (Foster City, CA).

\section{Statistical analysis}

The allele and genotype frequencies of rs9939609 were compared among ethnic groups, and the chi-square test was used to test their agreement with Hardy-Weinberg equilibrium in each group separately.

The mean anthropometric and dietary variables were compared between genotypes using analysis of variance (ANOVA) when normally distributed. The homogeneity of variances among the genotypic groups had previously been tested for each variable by the Levene's statistic, and non-parametric tests were used when appropriated. When ANOVA provided significant results, the Tukey post-hoc test for multiple comparisons was used.

The variables with non-normal distribution, such as the sum of skinfolds, were logarithmically transformed for analyses or compared by Kruskal-Wallis test when necessary.

The mean percent BMI variation between 12 to 16 months and 3 to 4 years of age was compared among genotypes and adjusted for the covariates of sex, age and intervention or control group, using General Linear Models (GLM). The BMI variation between 4 and 8 years of age was also compared among genotypes using a similar method.

Multilevel mixed models were also used to analyze genotype effects on the patterns of individual change in anthropometric and dietary variables over time, as described in $[19,20]$.

All statistical analyses were performed with SPSS version 20.0 for Windows software, and the differences were considered significant when $\mathrm{P}<0.05$.

\section{Results}

The genotypic frequencies (Table 1) agreed with those expected under Hardy-Weinberg equilibrium $(\mathrm{P}=0.099$
Table 1 Genotype and allele frequencies of FTO gene SNP rs9939609

\begin{tabular}{ccccc}
\hline Genotype & $\begin{array}{c}\text { Frequencies, } \\
\mathbf{n}(\%)\end{array}$ & \multicolumn{2}{c}{ Ethnicity } & P Value \\
\cline { 3 - 4 } & & $\begin{array}{c}\text { White, } \\
\mathbf{n}(\%)\end{array}$ & $\begin{array}{c}\text { Non-white, } \\
\mathbf{n}(\%)\end{array}$ & \\
\hline T/T & $130(37.4)$ & $59(42.4)$ & $63(34.6)$ & $0.273^{1}$ \\
T/A & $161(46.3)$ & $56(40.3)$ & $89(48.9)$ & \\
A/A & $57(16.4)$ & $24(17.3)$ & $30(16.5)$ & \\
A Alelle Frequency & 0.40 & 0.37 & 0.41 & $0.410^{1}$ \\
\hline${ }^{1}$ Chi-Square test. & & & &
\end{tabular}

for whites and $\mathrm{P}=0.879$ for non-whites). The allelic frequencies $(\mathrm{A}=40 \%)$ were similar to frequencies in other studies with European descendants [3,21,22].

The total sample was stratified between whites and nonwhites. No statistically significant differences were observed between these groups for allelic and genotypic frequencies (Table $1 ; \mathrm{P}=0.410$ and $\mathrm{P}=0.273$, respectively). No differences were observed regarding either anthropometric or dietary measurements among ethnicities, also. So, the individuals from both ethnicities were grouped in further analyses.

The mean anthropometric and dietary variables were compared among the different genotypes at the ages of 1, 4 and 8 years old (Table 2). There were no significant differences in phenotypes between genotypes at 1 year of age. At the age of 4 years old, we observed a statistically significant difference in the BMI Z-score among the three genotypic groups $(\mathrm{P}=0.036)$. After post-hoc analysis, we found that the $\mathrm{A} / \mathrm{A}$ individuals possessed a higher mean BMI Z-score than the T/A individuals $(\mathrm{P}=0.028)$. There was no evidence of an association between the FTO genotypes and the sum of skinfolds, the waist circumference, the total energy intake and the percent BMI variation between the ages of 1 and 4 years old.

When we analyzed the diet composition, we found a significant difference in the total energy intake from lipids between the three genotypes $(\mathrm{P}=0.014)$. The Tukey post-hoc test revealed that the $\mathrm{T} / \mathrm{T}$ genotype carriers had a higher mean of lipids intake than the T/A genotype $(P=0.013)$. When we adjusted the energy intake from lipids for BMI, this association was no longer significant ( $P=0.055$; data not shown). The total energy intake from carbohydrates was not different between genotypes.

Likewise, at 8 years of age we observed a statistically significant difference in the mean BMI Z-score among the FTO genotypes $(\mathrm{P}=0.011$; Table 2$)$. When the Tukey test was applied, we found that the carriers of the A/A genotype had higher means of BMI than the T/A carriers $(\mathrm{P}=0.014)$. For the other anthropometric parameters at the age of 8 , we observed that the sum of skinfolds showed marginally significant differences among the FTO genotypes. The percentage of BMI variation between the 
Table 2 Mean anthropometric parameters and dietary patterns according to FTO genotypes in the São Leopoldo cohort

\begin{tabular}{|c|c|c|c|c|c|c|c|}
\hline \multirow[t]{2}{*}{ Phenotypes } & \multicolumn{2}{|l|}{$\mathrm{T} / \mathrm{T}$} & \multicolumn{2}{|c|}{ T/A } & \multicolumn{2}{|l|}{$A / A$} & \multirow[t]{2}{*}{$P$} \\
\hline & Mean \pm SD & $\mathbf{n}$ & Mean \pm SD & $\mathbf{n}$ & Mean \pm SD & $\mathbf{n}$ & \\
\hline \multicolumn{8}{|l|}{1 year } \\
\hline BMI Z-score & $0.57 \pm 1.05$ & 129 & $0.55 \pm 1.02$ & 157 & $0.70 \pm 1.22$ & 56 & $0.615^{1}$ \\
\hline Total energy intake (kcal/day) & $946 \pm 369$ & 122 & $924 \pm 422$ & 144 & $891 \pm 405$ & 54 & $0.734^{2}$ \\
\hline Energy intake from lipids (kcal/day) & $261 \pm 120$ & 122 & $255 \pm 138$ & 144 & $238 \pm 142$ & 54 & $0.567^{1}$ \\
\hline Energy intake from carbohydrates (kcal/day) & $528 \pm 221$ & 122 & $517 \pm 240$ & 144 & $507 \pm 216$ & 54 & $0.830^{1}$ \\
\hline \multicolumn{8}{|l|}{4 years } \\
\hline BMI Z-score & $0.26 \pm 1.19^{6,7}$ & 125 & $0.13 \pm 0.98^{6}$ & 154 & $0.57 \pm 1.31^{7}$ & 54 & $0.036^{1}$ \\
\hline Sum of skinfolds (mm) & $13.4 \pm 4.5$ & 124 & $13.0 \pm 3.6$ & 152 & $15.0 \pm 6.2$ & 54 & $0.170^{3,4}$ \\
\hline Waist circumference $(\mathrm{cm})$ & $51.6 \pm 7.2$ & 126 & $51.3 \pm 7.4$ & 156 & $52.8 \pm 7.7$ & 55 & $0.394^{1}$ \\
\hline Total energy intake (kcal/day) & $1562 \pm 387$ & 121 & $1469 \pm 387$ & 154 & $1483 \pm 456$ & 55 & $0.145^{1}$ \\
\hline Energy intake from lipids (kcal/day) & $462 \pm 163^{8}$ & 121 & $410 \pm 133^{9}$ & 154 & $416 \pm 167^{8,9}$ & 55 & $0.014^{1}$ \\
\hline Energy intake from carbohydrates (kcal/day) & $869 \pm 235$ & 121 & $838 \pm 239$ & 154 & $856 \pm 264$ & 55 & $0.557^{1}$ \\
\hline BMI variation 1-4 years (\%) & $-9.20 \pm 8.96$ & 124 & $-9.97 \pm 8.01$ & 150 & $-7.46 \pm 10.42$ & 53 & $0.211^{5}$ \\
\hline \multicolumn{8}{|l|}{8 years } \\
\hline BMI Z-score & $0.48 \pm 1.25^{10,11}$ & 114 & $0.14 \pm 1.35^{10}$ & 141 & $0.78 \pm 1.60^{11}$ & 49 & $0.011^{1}$ \\
\hline Sum of skinfolds (mm) & $17.7 \pm 8.7$ & 114 & $16.6 \pm 7.0$ & 142 & $22.2 \pm 12.8$ & 49 & $0.048^{3,4}$ \\
\hline Waist circumference (cm) & $57.0 \pm 7.0$ & 114 & $56.1 \pm 5.5$ & 142 & $59.5 \pm 8.2$ & 49 & $0.054^{4}$ \\
\hline Total energy intake (kcal/day) & $1557 \pm 374$ & 113 & $1577 \pm 347$ & 141 & $1571 \pm 480$ & 49 & $0.911^{1}$ \\
\hline Energy intake from lipids (kcal/day) & $449 \pm 155$ & 113 & $457 \pm 139$ & 141 & $480 \pm 202$ & 49 & $0.495^{1}$ \\
\hline Energy intake from carbohydrates (kcal/day) & $890 \pm 218$ & 113 & $911 \pm 206$ & 141 & $871 \pm 252$ & 49 & $0.493^{1}$ \\
\hline BMI variation 8-4 years (\%) & $6.96 \pm 11.21$ & 109 & $3.60 \pm 10.63$ & 136 & $8.70 \pm 13.50$ & 46 & $0.015^{5}$ \\
\hline
\end{tabular}

Abbreviations: $B M I$, body mass index.

${ }^{1}$ Oneway ANOVA.

${ }^{2}$ General linear model including the covariate intervention group.

${ }^{3}$ Ln-transformed variable.

${ }^{4}$ Kruskal-Wallis test.

${ }^{5}$ General linear model including the covariates gender, age variation between phase $1 \mathrm{y}$ and phase $4 \mathrm{y}$ and intervention group.

6,7 Tukey test $\mathrm{T} / \mathrm{T} \times \mathrm{T} / \mathrm{A} \mathrm{P}=0.537 ; \mathrm{T} / \mathrm{A} \times \mathrm{A} / \mathrm{A} \mathrm{P}=0.028 ; \mathrm{T} / \mathrm{T} \times \mathrm{A} / \mathrm{A} \mathrm{P}=0.200$.

8,9 Tukey test $\mathrm{T} / \mathrm{T} \times \mathrm{T} / \mathrm{A} \mathrm{P}=0.013 ; \mathrm{T} / \mathrm{A} \times \mathrm{A} / \mathrm{A} \mathrm{P}=0.958 ; \mathrm{T} / \mathrm{T} \times \mathrm{A} / \mathrm{A} \mathrm{P}=0.151$

10,11 Tukey test $\mathrm{T} / \mathrm{T} \times \mathrm{T} / \mathrm{A} \mathrm{P}=0.118 ; \mathrm{T} / \mathrm{A} \times \mathrm{A} / \mathrm{A} \mathrm{P}=0.014 ; \mathrm{T} / \mathrm{T} \times \mathrm{A} / \mathrm{A} \mathrm{P}=0.403$.

ages of 4 to 8 also showed significant differences between the genotypes $(\mathrm{P}=0.015)$. The variables related to the dietary profile showed no significant differences between the genotypes at the age of 8 .

Longitudinal mixed models including anthropometric and dietary measurements as dependent variables and FTO $\mathrm{A} / \mathrm{A}$ genotype and sex (this last only when significant) as independent factors are shown in Table 3. In accordance with previous analyses, the A/A genotype was significantly associated with higher BMI Z-score $(\mathrm{P}=0.001)$, waist circumference $(P=0.001)$ and sum of skinfolds $(P=0.006)$, but not with total energy intake or energy from lipids or carbohydrates.

We analyzed the same gene variant in an independent sample of schoolchildren recruited in a nearby city, in the hopes of replicating these findings. The Sapucaia city is located only about $11 \mathrm{~km}$ of the first locality and the genotype frequencies of the FTO variant here investigated were similar in both samples $\left(\chi^{2}=2.819 ; \mathrm{df}=2 ; P=0.244\right)$. Significant differences in the mean BMI Z-score and the sum of skinfolds were found among the genotypes $(\mathrm{P}=0.029$ and $\mathrm{P}=0.016$, respectively; Table 4$)$. The Tukey test showed that the T/A genotype had higher means for the BMI Z-score $(\mathrm{P}=0.025)$ and the sum of skinfolds $(P=0.020)$ than did the $\mathrm{T} / \mathrm{T}$ genotype. The mean waist circumference was not different among genotypes.

The Sapucaia sample was further divided in children ( 4 to 10 years old, $n=293$ ) and adolescents (11 to 18 years old, $n=322$ ) and the anthropometric measurements were compared among genotypes in these subgroups. There were no significant differences in BMI Z-score, sum of skinfolds or waist circumference in children. In adolescents, the only statistical significant difference was observed in the sum of skinfolds (mean $\pm \mathrm{SD}, \mathrm{T} / \mathrm{T}=30.7 \pm 14.5 \mathrm{~mm}$; $\mathrm{T} / \mathrm{A}=34.4 \pm 14.8 \mathrm{~mm} ; \mathrm{A} / \mathrm{A}=36.2 \pm 14.5 \mathrm{~mm} ; P=0.020$ ), although for BMI Z-score, the $P$-value was 0.065 . This loss 
Table 3 Coefficients, s.e.s, and P-values from the best models for FTO rs9939609 predicting anthropometric and dietary variables in the São Leopoldo cohort

\begin{tabular}{|c|c|c|c|c|}
\hline Dependent variable & Effect & Coefficient & s.e. & P-value \\
\hline \multirow[t]{2}{*}{ BMI Z-score } & Intercept & 0.531 & 0.064 & $<0.001$ \\
\hline & $\mathrm{FTO}(0=\mathrm{T} / ? ; 1=\mathrm{A} / \mathrm{A})$ & 0.353 & 0.107 & 0.001 \\
\hline \multirow[t]{2}{*}{ Waist circumference } & Intercept & 51.6 & 0.5 & $<0.001$ \\
\hline & $\mathrm{FTO}(0=\mathrm{T} / ? ; 1=\mathrm{A} / \mathrm{A})$ & 2.6 & 0.8 & 0.001 \\
\hline \multirow[t]{3}{*}{ Ln $\Sigma$ skinfolds } & Intercept & 2.6 & 0.1 & $<0.001$ \\
\hline & $\mathrm{FTO}(0=\mathrm{T} / ? ; 1=\mathrm{A} / \mathrm{A})$ & 0.1 & 0.1 & 0.006 \\
\hline & $\operatorname{Sex}(0=F ; 1=M)$ & -0.1 & 0.1 & 0.014 \\
\hline \multirow[t]{3}{*}{ Total energy intake } & Intercept & 893.7 & 29.7 & $<0.001$ \\
\hline & $\mathrm{FTO}(0=\mathrm{T} / ? ; 1=\mathrm{A} / \mathrm{A})$ & -14.5 & 36.1 & 0.689 \\
\hline & $\operatorname{Sex}(0=F ; 1=M)$ & 68.3 & 26.9 & 0.011 \\
\hline \multirow[t]{3}{*}{ Energy from lipids } & Intercept & 245.9 & 10.2 & $<0.001$ \\
\hline & $\mathrm{FTO}(0=\mathrm{T} / ? ; 1=\mathrm{A} / \mathrm{A})$ & -1.0 & 13.4 & 0.939 \\
\hline & $\operatorname{Sex}(0=F ; 1=M)$ & 19.8 & 10.0 & 0.048 \\
\hline \multirow[t]{2}{*}{ Energy from carbohydrates } & Intercept & 523.6 & 14.3 & $<0.001$ \\
\hline & $\mathrm{FTO}(0=\mathrm{T} / ? ; 1=\mathrm{A} / \mathrm{A})$ & -18.2 & 21.1 & 0.390 \\
\hline
\end{tabular}

of significance can be due to the smaller sample size when the sample is reduced to about half of its size to perform these analyses.

\section{Discussion}

In the present study, we confirmed the association of the FTO variant rs9939609 with body mass index and related phenotypes in Brazilian children and adolescents. To our knowledge, this is the first study regarding this gene and phenotypes related to BMI in Latin American children and adolescents.

The frequency of the minor (A) allele found in Brazilian children was $40 \%$, similar to those reported in European cohorts of children and adolescents $[3,21,23]$ and similar to those reported for Brazilian adults from the same geographic region as ours [24,25].

After the first report identifying the association between the FTO gene and obesity-related phenotypes [3], several studies have confirmed the association between rs9939609 and increased BMI in populations of European children and adults [23,26-31] while negative results were found in some studies regarding populations of Oceanic [11], African [32,33] and Asian ancestries [10]. However, other studies have found significant associations in these populations [34-41]. The conflicting results among different ethnic populations are likely the result of varying degrees of linkage disequilibrium between SNPs, which suggests that the underlying causative variant is being tagged differently by rs9939609 in these populations $[9,23,32]$ or that there are different gene-environment interactions. The Brazilian population is, in general, highly admixed with contributions from Europeans, Africans and Native Americans to its gene pool. The Southern Brazilian population, which the present study targeted, differs from this general pattern; its inhabitants are mainly of European descent, with an African contribution estimated at approximately 8 to $13 \%$ [42]. The Native American contribution is fairly low. Our results show that the rs9939609 SNP is consistently associated with obesityrelated phenotypes in this population, even as early as

Table 4 Mean anthropometric parameters patterns according to FTO genotypes in the Sapucaia do Sul sample

\begin{tabular}{|c|c|c|c|c|c|c|c|}
\hline \multirow[t]{2}{*}{ Phenotypes } & \multicolumn{2}{|c|}{$\mathrm{T} / \mathrm{T}$} & \multicolumn{2}{|c|}{ T/A } & \multicolumn{2}{|c|}{$A / A$} & \multirow[t]{2}{*}{$P$} \\
\hline & Mean \pm SD & $\mathbf{n}$ & Mean \pm SD & $\mathbf{N}$ & Mean \pm SD & $\mathbf{n}$ & \\
\hline BMI Z-score & $0.43 \pm 1.39^{3}$ & 244 & $0.75 \pm 1.33^{4}$ & 293 & $0.70 \pm 1.50^{3,4}$ & 77 & $0.029^{1}$ \\
\hline Sum of skinfolds (mm) & $28.8 \pm 14.0^{5}$ & 245 & $31.6 \pm 13.7^{6}$ & 293 & $32.1 \pm 14.3^{5,6}$ & 77 & $0.016^{1,2}$ \\
\hline Waist circumference $(\mathrm{cm})$ & $69.2 \pm 11.5$ & 245 & $70.2 \pm 11.8$ & 293 & $69.1 \pm 12.4$ & 77 & $0.550^{1}$ \\
\hline
\end{tabular}

Abbreviations: $B M I$, body mass index.

1 Oneway ANOVA.

${ }^{2}$ Statistical tests performed with In-transformed variable.

${ }^{3,4}$ Tukey test $\mathrm{T} / \mathrm{T} \times \mathrm{T} / \mathrm{A} \mathrm{P}=0.025 ; \mathrm{T} / \mathrm{A} \times \mathrm{A} / \mathrm{A} \mathrm{P}=0.967 ; \mathrm{T} / \mathrm{T} \times \mathrm{A} / \mathrm{A} \mathrm{P}=0.298$.

${ }^{5,6}$ Tukey test $\mathrm{T} / \mathrm{T} \times \mathrm{T} / \mathrm{A} \mathrm{P}=0.020 ; \mathrm{T} / \mathrm{A} \times \mathrm{A} / \mathrm{A} \mathrm{P}=0.985 ; \mathrm{T} / \mathrm{T} \times \mathrm{A} / \mathrm{A} \mathrm{P}=0.127$. 
4 years old. Although this SNP is located in an intron and several studies have shown a strong genetic disequilibrium in this gene region, it is not possible at this time to rule out rs9939609 as a functional variant [4]. Rather, it is necessary to refine the strength and exact nature of the genetic signal that is functionally related to obesity or related traits [4].

Although several studies have reliably confirmed, to varying degrees, the association between the variation at FTO, BMI and related phenotypes [43], there is still some controversy regarding when FTO gene function begins to take effect. In our research, the FTO gene was not associated with any variable for 1 -year-old children. We were only able to find an association of the A/A genotype of rs9939609 and a higher BMI Z-score by the age of 4 . This finding agrees with a recent meta-analysis performed on 8 cohorts of European ancestry [43]. In that study, the authors suggested that the variation at FTO is associated with a shift in the timing of adiposity rebound; the additive effects of the A allele accelerated developmental age by approximately $2.4 \%$ per allele, which corresponded to an early adiposity rebound and a higher BMI later in childhood. According to these data, our longitudinal analysis has shown a greater BMI variation between the ages of 4 and 8 in the A/A subjects.

When we followed the same sample of children until 8 years old, we again found an association between the FTO genotypes and the BMI; the A/A homozygotes had higher mean BMI Z-scores than the children carrying one copy of the rs9939609 variant. The A/A genotype was also marginally associated with increased subcutaneous fat, evaluated through the sum of skinfolds. These findings are corroborated by previous childhood [31] and adolescents [44] studies. Furthermore, these results were replicated in an independent sample of schoolchildren between 5 and 18 years of age. In this second sample, the carriers of the T/A genotype possessed a higher BMI Z-score and more skinfolds than the T/T genotype. However, in these older children, the T/A and A/A individuals showed similar means of these two parameters, which diverges somewhat from the results in the first cohort, where the A/A and T/A genotype groups were different. Previous works indicate an additive effect of the A-allele $[3,22,43,45]$. In all cross-sectional and longitudinal analyses performed, it can be observed that the significant differences regarding $\mathrm{BMI}$ are between the T/A and A/A genotypes in the cohort of São Leopoldo, which suggest that, in these young children, there is an recessive effect of the A allele on BMI. However, we cannot exclude the possibility that the difference between the $\mathrm{A} / \mathrm{A}$ and $\mathrm{T} / \mathrm{T}$ genotypes may have not been observed due to the moderate sample size evaluated herein or to some environmental or gene-gene interaction that cannot have been addressed with the current approach.
It has been hypothesized that the FTO gene has been associated with obesity because it can influence energy homeostasis by having a direct effect on food intake in animal models [46]. A study recently published by Larder et al. (2011) [47] suggests that the increased consumed energy in risk allele carriers is due to a major preference for energy-dense foods, specifically those with a higher fat content, rather than a general increase in the amount of food consumed. However, our data do not seem to corroborate this hypothesis. When we analyzed dietary composition, we observed that the A/A children consumed less energy from lipids by the age of 4 . We hypothesized that this reduction in fat consumption in the 4-year-old children with the A/A genotype could be the result of greater parental diet control because this group possessed a higher BMI. In fact, when we adjusted the energy intake from lipids for BMI, the former association was no longer significant. Accordingly, at 8 years old, the association between the dietary composition and the FTO genotypes in our sample disappears and, unfortunately, in the independent sample the dietary patterns were not available. As stated previously, the exact role of the FTO gene product in the regulation of human energy metabolism is still unclear, and our findings do not suggest a higher total energy intake in the A-allele carriers.

It is known that the FTO is expressed in the hypothalamus, mainly in the arcuate nucleus, which is responsible for controlling appetitive behavior $[6,48]$. The FTO variants may also influence macronutrient choice because the arcuate nuclei contains key neuronal populations that make up the central melanocortin pathway, and studies in mice have shown that Fto is expressed within proopiomelanocortin neurons. A reduction in central melanocortin tone has been linked to an increase dietary preference for fat [49]. Thus, it is possible that FTO variants are able, either directly or indirectly, to modulate hypothalamic melanocortin activity [47].

A recent study in mice reported the relationship of FTO and the epigenetic process. The FTO gene has been proposed as a transcriptional coativator that enhances the transactivation potential of the CCAAT/enhancer binding proteins (C/EBPs) from unmethylated as well as methylation-inhibited gene promoters, which suggests a role in the epigenetic regulation of development and maintenance of fat tissue [50]. While the exact function of the FTO gene remains to be clarified, it becomes difficult to speculate the mechanism underlying these findings.

There are some limitations to our study. First, the sample size is lower than in other studies; although even under these conditions, we were able to replicate the previous associations of FTO SNPs and increased BMI in children and adolescents. Another limitation is that our replication sample data were cross-sectional and detailed food intake data were not available, which 
precludes deeper analyses in this sample. Furthermore, only $127(20.7 \%)$ of the children of the Sapucaia sample were in the same age range of the São Leopoldo cohort. On the other hand, relevant data are brought by this second sample exactly due to the fact that it comprehends children and adolescents of a higher age and allows us to infer if that the findings in younger children can be extended until the age 18.

\section{Conclusion}

Overall, our work presents new data regarding associations of the FTO gene in a previously unexplored population and confirms worldwide data regarding the influence of this gene on the genetic susceptibility for an increased BMI and specific adiposity measures. Furthermore, we were able to show, through a longitudinal analysis that this effect begins around the age of 3 to 4 . The exact role of the FTO gene in body weight regulation as well as the functionality of the rs9939609 variant remain to be elucidated, but this genetic association is, undoubtedly, the most consistent finding to date.

\section{Abbreviations \\ BMl: Body mass index; C/EBPs: CCAAT/enhancer binding proteins; FTO: Fat mass and obesity gene; GWAs: Genome wide association studies; HIV: Human immunodeficiency virus; T2DM: Type 2 diabetes mellitus; SNP: Single nucleotide polymorphism; WHO: World Health Organization.}

\section{Competing interests}

The authors declare that they have no competing interests.

\section{Authors' contributions}

CFS genotyped the patients, performed the statistical analyses and wrote the manuscript. MRZ participated of the Sapucaia data and sample collection, DNA extractions and statistical analyses. MRV and PDBC were responsible for all the São Leopoldo cohort selection, following, nutritional evaluation and sample collection. LNR was responsible for all the Sapucaia sample selection, evaluation and sample collection. SA participated in the study design, statistical analyses and manuscript writing. VSM conceived and designed the experiments and coordinated the genotyping, statistical analyses and manuscript writing. All authors read and approved the final manuscript.

\section{Acknowledgments}

This work was supported by Conselho Nacional de Desenvolvimento Científico e Tecnológico (CNPq, Brazil), Fundação de Amparo à Pesquisa do Estado do Rio Grande do Sul (FAPERGS, Brazil) and PRONEX/FAPERGS/CNPq.

\section{Author details}

'Programa de Pós-Graduação em Patologia, Universidade Federal de Ciências da Saúde de Porto Alegre, Porto Alegre, RS, Brazil. ${ }^{2}$ Programa de Pós-Graduação em Ciências da Saúde, Universidade Federal de Ciências da Saúde de Porto Alegre, Porto Alegre, RS, Brazil. ${ }^{3}$ Universidade Federal de Ciências da Saúde de Porto Alegre, Rua Sarmento Leite, 245, sala 309, CEP 90050-170, Porto Alegre, RS, Brazil.

Received: 8 June 2012 Accepted: 7 March 2013

Published: 13 March 2013

\section{References}

1. World Health Organization: http://www.who.int/mediacentre/factsheets/ fs311/en/index.html.

2. Groop L: From fused toes in mice to human obesity. Nat Genet 2007, 39(6):706-707.

3. Frayling $T M$, Timpson $N J$, Weedon $M N$, Zeggini $E$, Freathy RM, Lindgren $C M$, Perry JR, Elliott KS, Lango H, Rayner NW, et al: A common variant in the
FTO gene is associated with body mass index and predisposes to childhood and adult obesity. Science 2007, 316(5826):889-894.

4. Loos RJ, Bouchard C: FTO: the first gene contributing to common forms of human obesity. Obes Rev 2008, 9(3):246-250.

5. Rendo T, Moleres A, Marti Del Moral A: Effects of the FTO gene on lifestyle intervention studies in children. Obes Facts 2009, 2(6):393-399.

6. Gerken T, Girard CA, Tung YC, Webby CJ, Saudek V, Hewitson KS, Yeo GS, McDonough MA, Cunliffe S, McNeill LA, et al: The obesity-associated FTO gene encodes a 2-oxoglutarate-dependent nucleic acid demethylase. Science 2007, 318(5855):1469-1472.

7. Fredriksson R, Hagglund M, Olszewski PK, Stephansson O, Jacobsson JA, Olszewska AM, Levine AS, Lindblom J, Schioth HB: The obesity gene, FTO, is of ancient origin, up-regulated during food deprivation and expressed in neurons of feeding-related nuclei of the brain. Endocrinology 2008, 149(5):2062-2071.

8. Villalobos-Comparan M, Teresa Flores-Dorantes $M$, Teresa Villarreal-Molina M, Rodriguez-Cruz M, Garcia-Ulloa AC, Robles L, Huertas-Vazquez A, SaucedoVillarreal N, Lopez-Alarcon M, Sanchez-Munoz F, et al: The FTO gene is associated with adulthood obesity in the Mexican population. Obesity (Silver Spring) 2008, 16(10):2296-2301.

9. Bressler J, Kao WHL, Pankow JS, Boerwinkle E: Risk of type 2 diabetes and obesity is differentially associated with variation in FTO in whites and African-Americans in the ARIC study. PLoS One 2010, 5(5):e10521.

10. Li H, Wu Y, Loos RJ, Hu FB, Liu Y, Wang J, Yu Z, Lin X: Variants in the fat mass- and obesity-associated (FTO) gene are not associated with obesity in a Chinese Han population. Diabetes 2008, 57(1):264-268.

11. Ohashi J, Naka I, Kimura R, Natsuhara K, Yamauchi T, Furusawa T, Nakazawa M, Ataka Y, Patarapotikul J, Nuchnoi P, et al: FTO polymorphisms in oceanic populations. J Hum Genet 2007, 52(12):1031-1035.

12. Liu G, Zhu H, Lagou V, Gutin B, Stallmann-Jorgensen IS, Treiber FA, Dong Y Snieder H: FTO variant rs9939609 is associated with body mass index and waist circumference, but not with energy intake or physical activity in European- and African-American youth. BMC Med Genet 2010, 11:57.

13. Gonzalez-Sanchez JL, Zabena C, Martinez-Larrad MT, Martinez-Calatrava MJ, Perez-Barba M, Serrano-Rios M: Variant rs9939609 in the FTO gene is associated with obesity in an adult population from Spain. Clin Endocrinol (Oxf) 2009, 70(3):390-393

14. Vitolo MR, Bortolini GA, Feldens CA, Drachler ML: Impacts of the 10 steps for healthy feeding in infants: a randomized field trial. Cad Saude Publica 2005, 21(5):1448-1457.

15. Vitolo MR, Rauber F, Campagnolo PD, Feldens CA, Hoffman DJ: Maternal dietary counseling in the first year of life is associated with a higher healthy eating index in childhood. J Nutr 2010, 140(11):2002-2007.

16. Philippi ST (Ed): Tabela de Composição de Alimentos - Suporte para Decisão Nutricional. 2nd edition. São Paulo: Metha; 2002.

17. UNICAMP: Tabela Brasileira de Composição de Alimentos - TACO. 2nd edition. São Paulo: NEPA/UNICAMP; 2006.

18. Lahiri DK, Nurnberger JI Jr: A rapid non-enzymatic method for the preparation of HMW DNA from blood for RFLP studies. Nucleic Acids Res 1991, 19(19):5444.

19. Hallman DM, Srinivasan SR, Elkasabany A, Boerwinkle E, Berenson GS: The Ser (447)-Stop polymorphism of lipoprotein lipase is associated with variation in longitudinal serum high-density lipoprotein-cholesterol profiles: the Bogalusa Heart Study. Metabolism 2001, 50(8):894-904.

20. Hallman DM, Friedel VC, Eissa MA, Boerwinkle E, Huber JC Jr, Harrist RB, Srinivasan SR, Chen W, Dai S, Labarthe DR, et al: The association of variants in the FTO gene with longitudinal body mass index profiles in non-Hispanic white children and adolescents. Int J Obes (Lond) 2012, 36(1):61-68.

21. Dina C, Meyre D, Gallina S, Durand E, Korner A, Jacobson P, Carlsson LM, Kiess W, Vatin V, Lecoeur C, et al: Variation in FTO contributes to childhood obesity and severe adult obesity. Nat Genet 2007, 39(6):724-726.

22. Hinney A, Nguyen $T$, Scherag A, Friedel S, Bronner G, Muller TD, Grallert $H_{4}$ Illig T, Wichmann HE, Rief W, et al: Genome wide association (GWA) study for early onset extreme obesity supports the role of fat mass and obesity associated gene (FTO) variants. PLoS One 2007, 2(12):e1361.

23. Scuteri A, Sanna S, Chen WM, Uda M, Albai G, Strait J, Najijar S, Nagaraja R, Orru M, Usala G, et al: Genome-wide association scan shows genetic variants in the FTO gene are associated with obesity-related traits. PLOS Genet 2007, 3(7):e115.

24. Ramos RB, Casanova GK, Maturana MA, Spritzer PM: Variations in the fat mass and obesity-associated (FTO) gene are related to glucose levels 
and higher lipid accumulation product in postmenopausal women from southern Brazil. Fertil Steril 2011, 96(4):974-979.

25. Steemburgo T, de Azevedo MJ, Gross JL, Milagro F, Campion J, Martinez JA: The rs7204609 polymorphism in the fat mass and obesity-associated gene is positively associated with central obesity and microalbuminuria in patients with type 2 diabetes from Southern Brazil. J Ren Nutr 2012, 22(2):228-236.

26. Cornes BK, Lind PA, Medland SE, Montgomery GW, Nyholt DR, Martin NG Replication of the association of common rs9939609 variant of FTO with increased BMI in an Australian adult twin population but no evidence for gene by environment ( $\mathrm{G}$ x E) interaction. Int J Obes (Lond) 2009, 33(1):75-79.

27. Cauchi S, Stutzmann F, Cavalcanti-Proenca C, Durand E, Pouta A, Hartikainen AL, Marre M, Vol S, Tammelin T, Laitinen J, et al: Combined effects of MC4R and FTO common genetic variants on obesity in European general populations. J Mol Med 2009, 87(5):537-546.

28. Jacobsson JA, Danielsson P, Svensson V, Klovins J, Gyllensten U, Marcus $C_{\text {, }}$ Schioth $H B$, Fredriksson R: Major gender difference in association of FTO gene variant among severely obese children with obesity and obesity related phenotypes. Biochem Biophys Res Commun 2008, 368(3):476-482.

29. Hubacek JA, Bohuslavova R, Kuthanova L, Kubinova R, Peasey A, Pikhart H, Marmot MG, Bobak M: The FTO gene and obesity in a large Eastern European population sample: the HAPIEE study. Obesity (Silver Spring) 2008, 16(12):2764-2766.

30. Wardle J, Carnell S, Haworth CM, Farooqi IS, O'Rahilly S, Plomin R: Obesity associated genetic variation in FTO is associated with diminished satiety. J Clin Endocrinol Metab 2008, 93(9):3640-3643.

31. Cecil JE, Tavendale R, Watt P, Hetherington MM, Palmer CN: An obesity-associated FTO gene variant and increased energy intake in children. N Engl J Med 2008, 359(24):2558-2566.

32. Grant SF, Li M, Bradfield JP, Kim CE, Annaiah K, Santa E, Glessner JT, Casalunovo T, Frackelton EC, Otieno FG, et al: Association analysis of the FTO gene with obesity in children of Caucasian and African ancestry reveals a common tagging SNP. PLoS One 2008, 3(3):e1746.

33. Hennig BJ, Fulford AJ, Sirugo G, Rayco-Solon P, Hattersley AT, Frayling TM, Prentice AM: FTO gene variation and measures of body mass in an African population. BMC Med Genet 2009, 10:21.

34. Yajnik CS, Janipalli CS, Bhaskar S, Kulkarni SR, Freathy RM, Prakash S, Mani KR, Weedon MN, Kale SD, Deshpande J, et al: FTO gene variants are strongly associated with type 2 diabetes in South Asian Indians. Diabetologia 2009, 52(2):247-252

35. Rees SD, Islam M, Hydrie MZ, Chaudhary B, Bellary S, Hashmi S, O'Hare JP, Kumar S, Sanghera DK, Chaturvedi N, et al: An FTO variant is associated with Type 2 diabetes in South Asian populations after accounting for body mass index and waist circumference. Diabet Med 2011, 28(6):673-680.

36. Karasawa S, Daimon M, Sasaki S, Toriyama S, Oizumi T, Susa S, Kameda W, Wada K, Muramatsu M, Fukao A, et al: Association of the common fat mass and obesity associated (FTO) gene polymorphism with obesity in a Japanese population. Endocr J 2010, 57(4):293-301.

37. Cha SW, Choi SM, Kim KS, Park BL, Kim JR, Kim JY, Shin HD: Replication of genetic effects of FTO polymorphisms on BMI in a Korean population. Obesity (Silver Spring) 2008, 16(9):2187-2189.

38. Chang Y-C, Liu P-H, Lee W-J, Chang T-J, Jiang Y-D, Li H-Y, Kuo S-S, Lee K-C, Chuang L-M: Common variation in the fat mass and obesity-associated (FTO) gene confers risk of obesity and modulates BMI in the Chinese population. Diabetes 2008, 57:2245-2252.

39. Tan J, Dorajoo R, Seielstad M, Sim XL, Ong RT, Chia KS, Wong TY, Saw SM, Chew SK, Aung T, et al: FTO variants are associated with obesity in the Chinese and Malay populations in Singapore. Diabetes 2008, 57(10):2851-2857.

40. Hassanein MT, Lyon HN, Nguyen TT, Akylbekova EL, Waters K, Lettre G, Tayo B, Forrester T, Sarpong DF, Stram DO, et al: Fine mapping of the association with obesity at the FTO locus in African-derived populations. Hum Mol Genet 2010, 19(14):2907-2916.

41. Liu Y, Liu Z, Song Y, Zhou D, Zhang D, Zhao T, Chen Z, Yu L, Yang Y, Feng $G$, et al: Meta-analysis added power to identify variants in FTO associated with type 2 diabetes and obesity in the Asian population. Obesity (Silver Spring) 2010, 18(8):1619-1624

42. Zembrzuski VM, Callegari-Jacques SM, Hutz MH: Application of an African Ancestry Index as a genomic control approach in a Brazilian population. Ann Hum Genet 2006, 70(Pt 6):822-828.

43. Sovio U, Mook-Kanamori DO, Warrington NM, Lawrence R, Briollais L, Palmer CN, Cecil J, Sandling JK, Syvanen AC, Kaakinen M, et al: Association between common variation at the FTO locus and changes in body mass index from infancy to late childhood: the complex nature of genetic association through growth and development. PLoS Genet 2011, 7(2):e1001307.

44. Mangge H, Renner W, Almer G, Weghuber D, Moller R, Horejsi R: Rs9939609 variant of the fat mass and obesity-associated gene and trunk obesity in adolescents. J Obes 2011, 2011:186368.

45. Sonestedt E, Roos C, Gullberg B, Ericson U, Wirfalt E, Orho-Melander M: Fat and carbohydrate intake modify the association between genetic variation in the FTO genotype and obesity. Am J Clin Nutr 2009, 90(5):1418-1425.

46. Tung YC, Ayuso E, Shan X, Bosch F, O'Rahilly S, Coll AP, Yeo GS: Hypothalamic-specific manipulation of Fto, the ortholog of the human obesity gene FTO, affects food intake in rats. PLoS One 2010, 5(1):e8771.

47. Larder R, Cheung MK, Tung YC, Yeo GS, Coll AP: Where to go with FTO? Trends Endocrinol Metab 2011, 22(2):53-59.

48. Stratigopoulos G, Padilla SL, LeDuc CA, Watson E, Hattersley AT, McCarthy Ml, Zeltser LM, Chung WK, Leibel RL: Regulation of Fto/Ftm gene expression in mice and humans. Am J Physiol Regul Integr Comp Physiol 2008, 294(4):R1185-R1196.

49. Tung YC, Rimmington D, O'Rahilly S, Coll AP: Pro-opiomelanocortin modulates the thermogenic and physical activity responses to high-fat feeding and markedly influences dietary fat preference. Endocrinology 2007, 148(11):5331-5338.

50. Han Z, Niu T, Chang J, Lei X, Zhao M, Wang Q, Cheng W, Wang J, Feng Y, Chai J: Crystal structure of the FTO protein reveals basis for its substrate specificity. Nature 2010, 464(7292):1205-1209.

doi:10.1186/1471-2350-14-34

Cite this article as: da Silva et al:: Association between a frequent variant of the FTO gene and anthropometric phenotypes in Brazilian children. BMC Medical Genetics 2013 14:34.

\section{Submit your next manuscript to BioMed Central and take full advantage of:}

- Convenient online submission

- Thorough peer review

- No space constraints or color figure charges

- Immediate publication on acceptance

- Inclusion in PubMed, CAS, Scopus and Google Scholar

- Research which is freely available for redistribution 